\title{
Associations between hyperglycaemia and somatic transversion mutations in mitochondrial DNA of people with diabetes mellitus
}

\author{
J. Kamiya, Y. Aoki \\ The Second Department of Internal Medicine, Shinshu University School of Medicine, Matsumoto-city, Nagano-prefecture, Japan
}

\begin{abstract}
Aims/hypothesis. Considering that increased oxidative stress induced by hyperglycaemia plays a possible role in the pathogenesis of diabetic complications and that mitochondrial DNA (mDNA) is thought to be more vulnerable than nuclear DNA, we investigated what somatic mutations actually occur in the mDNA of diabetic patients. We also studied the relations between those mutations and urinary 8-hydroxy-2'-deoxyguanosine $(8-\mathrm{OHdG})$ which is known to increase considerably in people with diabetes.

Methods. We identified somatic mutations by subcloning and sequencing two segments of mDNA [control region (nt 15996-16401) and the segment encompassing $t-R N A^{\operatorname{Leu}(U U R)}$ (nt 3149-3404)] in the peripheral blood cells of six diabetic women and control subjects matched for age and sex. This was done in 20 colonies each. In each case we also assayed urinary 8-OHdG.

Results. No difference in the aggregate somatic mutational burden of mDNA was found between patients
\end{abstract}

and control subjects. However, the incidence of somatic transversion mutations in mDNA was significantly higher in diabetic patients than in control subjects $\left(13.93 \pm 4.57 \times 10^{-5}\right.$ vs $1.27 \pm 1.27 \times 10^{-5}$ mutations per base pair; $p=0.031$, according to Mann-Whitney U-test). There was no significant difference in transition mutations. A correlation was found between the transversion mutational burden and $\mathrm{HbA}_{1} \mathrm{c}$ values, but not between it and 8-OHdG content in the urine.

Conclusions/interpretation. We showed that somatic transversion point mutations of mDNA increase in diabetic patients. Such transversion mutations can become a new biomarker for mDNA damage associated with hyperglycaemia and possibly caused by oxidative stress but not reflected by urinary $8-\mathrm{OHdG}$. [Diabetologia (2003) 46:1559-1566]

Keywords Hyperglycaemia, mitochondrial DNA, point mutations, diabetic complications, oxidative stress.
Received: 5 May 2003 / Revised: 9 July 2003

Published online: 7 October 2003

(C) Springer-Verlag 2003

Corresponding author: Dr. J. Kamiya, The Second Department of Internal Medicine, Shinshu University School of Medicine, 3-1-1 Asahi, Matsumoto-city, Nagano-prefecture, 390-8621 Japan

E-mail: jkamiyan@hsp.md.shinshu-u.ac.jp

Abbreviations: mDNA, mitochondrial DNA; nDNA, nuclear DNA; 8-OHdG, 8-hydroxy-2'-deoxyguanosine; A, adenine; $\mathrm{G}$, guanine; $\mathrm{T}$, thymine; $\mathrm{C}$, cytosine; ROS, reactive oxygen species.
Oxidative stress is a disturbance in the pro-oxidant [reactive oxygen species (ROS)] and antioxidant balance in favour of the pro-oxidant state $[1,2]$. Increased oxidative stress has been found in people with diabetes, presumably contributing to diabetic microand macroangiopathic complications $[3,4,5,6,7,8$, $9,10,11,12,13,14]$. One form of oxidative damage to cellular macromolecules, mutations in mitochondrial DNA (mDNA) have been noted as a possible consequence of DNA damage $[13,15,16]$. Most experiments on diabetes mellitus have been directed to large mDNA deletion $[13,15]$, and experiments on somatic point mutations have been very limited [16]. Somatic point mutations have also been investigated in con- 
nection with aging or age-related diseases $[17,18,19$, 20].

MDNA has a higher frequency of somatic mutations than nuclear DNA (nDNA). Deamination and methylation are thought to bring about transition mutations, i.e. the substitution of one purine or one pyrimidine base for its respective other, in nDNA and mDNA $[21,22,23]$. Both processes often occur in vivo [24]. Transversion mutations occur in the same way through oxidative damage caused by 8 -hydroxy$2^{\prime}$-deoxyguanosine $(8-\mathrm{OHdG})[25,26,27,28,29,30]$. Along with these mutations, mitochondria are also likely to have fewer repair enzymes, e.g. glycosylase, for base excision repair than the nucleus has [31], and no nucleotide excision repair capacities [32]. MDNA is also located near the respiratory chain, potentially generating ROS. In addition, mDNA has no histone proteins, which protect DNA from deamination, methylation or oxidation [23,33]. As a result, mDNA is thought to have a higher mutability and subsequently acquire 5 to 20 times as many somatic mutations as nDNA $[34,35]$.

Because of its abundance and mutagenicity 8-OHdG has been reported to be the most important indicator of oxidative DNA damage [5, 25, 36]. This 8 -OHdG comes from an oxidative reaction to the guanine $(\mathrm{G})$ base, which is highly susceptible to oxidative stress, since it has the lowest oxidation potential among bases. The substance $8-\mathrm{OHdG}$ promotes the formation of Watson-Crick pairs not only with cytosine $(\mathrm{C})$, but also with adenine (A), and can give rise to $\mathrm{G}: \mathrm{C}$ site to thymine (T):A site or T:A site to $\mathrm{G}: \mathrm{C}$ site transversion point mutations (substitution of a purine base for a pyrimidine base or vice-versa; referred to below as "8-OHdG-associated mutations") $[25,37$, 38]. The amount of $8-\mathrm{OHdG}$ is reportedly larger in the DNA and urine of people with diabetes than in those of non-diabetic people $[5,7,9]$. Urinary $8-\mathrm{OHdG}$ is a familiar marker of oxidative stress, because it is quite stable in the urine and not easily affected by foods $[39,40]$.
We therefore attempted to identify the kinds of mutations that can actually be induced in the mDNA of patients with diabetes mellitus, while concurrently assaying urinary $8-\mathrm{OHdG}$.

\section{Subjects and methods}

Subjects. Patients were recruited from the outpatient department of the Shinshu University Hospital. For the control group non-diabetic subjects of the same sex and age were selected at random. All participants gave their written informed consent before enrolling in the study, which was approved by the Ethics Committee of Shinshu University School of Medicine, Matsumoto, Japan. The type of diabetes was diagnosed according to the 1998 criteria of the World Health Organization [41]. Diabetic retinopathy diagnosed by funduscopy was designated as a marker of microangiopathy. One patient had clinically overt macroangiopathy (cerebral infarction). There were no active smokers among our subjects, whose characteristics are shown in Table 1. Postprandial peripheral blood and urine samples were taken from each subject. The blood samples were subjected to DNA extraction and urine samples were frozen at $-20^{\circ} \mathrm{C}$ until analysis.

DNA extraction and subcloning. DNA was extracted from peripheral blood cells using a DNA Extractor WB kit (NaI method; Wako Pure Chemical Industries, Osaka, Japan). The extracted DNA (0.5 to $1.0 \mu \mathrm{g}$ ) was subjected to a PCR with Taq DNA polymerase (Takara Bio Shiga, Japan) to amplify two segments of mDNA (GenBank J01415), nt 15997 to 16400 (forward primer, 5'-CCA CCA TTA GCA CCC AAA GC-3': backward primer, 5'-TGA TTT CAC GGA GGA TGG TG-3'), and nt 3150 to 3403 (forward primer, 5'-AGG ACA AGA GAA ATA AGG CC-3': backward primer, 5'-CAC GTT GGG GCC TTT GCG TA-3'). The former (segment A) is a hypervariable segment, the latter (segment B) is a segment encompassing the $t-R N A^{\text {Leu }(U U R)}$ gene. PCR was done in only 12 cycles consisting of denaturation at $94^{\circ} \mathrm{C}$, annealing at $55^{\circ} \mathrm{C}$ and extension at $72^{\circ} \mathrm{C}$ for $1 \mathrm{~min}$ each. The PCR products were electrophoresed on a $1.5 \%$ (wt/vol) agarose gel with a Readyto-Load 100 bp ladder (Invitrogen, Carlsbad, Calif., USA) running in parallel for approximate PCR product band sizing and stained by ethidium bromide for $15 \mathrm{~min}$. Proper bands at the size of 444 bps (segment A) or 294 bps (segment B) were then cut out, and the PCR products were purified by a GFX PCR

Table 1. Characteristics of diabetic and non-diabetic control subjects

Diabetic patients

\begin{tabular}{|c|c|c|c|c|c|c|c|c|c|c|}
\hline $\begin{array}{l}\text { Patient } \\
\text { no. } \\
(n=6)\end{array}$ & $\begin{array}{l}\text { Age } \\
(\text { years }) / \\
\text { sex }\end{array}$ & $\begin{array}{l}\text { Type of } \\
\text { diabetes }\end{array}$ & $\begin{array}{l}\text { Duration of } \\
\text { diabetes } \\
\text { (years) }\end{array}$ & Treatment & Complications & $\begin{array}{l}\mathrm{HbA}_{1} \mathrm{c} \\
(\%)\end{array}$ & $\begin{array}{l}\text { Control } \\
\text { no. } \\
(n=6)\end{array}$ & $\begin{array}{l}\text { Age } \\
\text { (years)/ } \\
\text { sex }\end{array}$ & $\begin{array}{l}\mathrm{HbA}_{1} \mathrm{c} \\
{[\%]}\end{array}$ & Comments \\
\hline DM_2 & $47 / \mathrm{F}$ & Type 2 & 2 & OHA & None & 7.5 & Cont_2 & $46 / \mathrm{F}$ & 5.0 & None \\
\hline DM_3 & $53 / \mathrm{F}$ & Others* & 29 & Insulin & Micro & 10.2 & Cont_3 & $52 / \mathrm{F}$ & 5.2 & None \\
\hline DM_4 & $63 / \mathrm{F}$ & Type 1 & 32 & Insulin & Micro & 8.0 & Cont_4 & $63 / F$ & 5.0 & Hyperlipidaemia \\
\hline
\end{tabular}

*This patient had 2/20 A3243G point mutations, which were excluded as germ-line mutations in heteroplasmy.
DM_1, 2 etc., diabetic patient no. 1, 2 etc.; Cont_1, 2 etc., control subject no. 1, 2 etc.; OHA, oral hypoglycaemic agent; Micro, microangiopathy; Macro, macroangiopathy 
DNA and Gel Band Purification Kit (Amersham Pharmacia Biotech, Piscataway, N.J., USA). The purified PCR products were ligated into a pCR2.1 vector and transformed into competent cells of Escherichia coli by using an Original TA cloning Kit (Invitrogen). The transformed cells were then spread onto LB agar plates containing $143.1 \mu \mathrm{mol} / 1$ of ampicillin with $40 \mu \mathrm{l}$ of 5 -Bromo-4-chloro-3-indolyl- $\beta$-D-galactopyranoside (X-Gal) stock solution (48.9 $\mathrm{mmol} / \mathrm{l})$.

Sequencing of $m D N A$. Recombinant plasmids isolated from 20 white colonies per patient or control subject were subjected to sequencing with a dye terminator cycle sequencing kit (PerkinElmer, Foster, Calif., USA). The array of mDNA sequences was determined by using the ABI PRISM 310 Genetic Analyzer (Applied Biosystems, Foster, Calif., USA) and comparing carefully with the revised Cambridge Reference Sequence [42]. The mutations identified in all clones (homoplasmy) are referred to as "germ-line mutations" and the other heteroplasmic mutations as "somatic mutations". The two A3243G transition mutations from 20 colonies in patient DM_3 (Table 1) were the only exceptions. They were qualified as germ-line mutations in heteroplasmy, because her daughter had been found to have mitochondrial diabetes.

Urinary 8-OHdG assay. The $8-\mathrm{OHdG}$ in the urine was measured by enzyme-linked immunosorbent assay [43]. The intraand inter-assay coefficients of variation were $6.0 \%$ and $8.6 \%$ respectively. We calculated the urinary $8-\mathrm{OHdG}$ by dividing 8 OHdG by creatinine per unit volume of urine.

HL-60 cell culture. The HL-60 human promyelocytic/myeloblastic cell line was purchased from the American Type Culture Collection (Rockville, Md., USA) and maintained in a RPMI 1640 medium (11.1 mmol/l glucose; Nikken BioMedical Laboratory, Kyoto, Japan), supplemented with $10 \%$ fetal bovine serum (Life Technologies, Grand Island, N.Y., USA) and 1\% antibiotic-antimycotic $(100 \mathrm{U} / \mathrm{ml}$ penicillin $\mathrm{G}$ sodium, $171.9 \mu \mathrm{mol} / \mathrm{l}$ streptomycin and $270.5 \mathrm{nmol} / \mathrm{l}$ amphotericin $\mathrm{B}$; Invitrogen). The HL60 cells were divided into two groups, which were further cultured with glucose concentrations of 5.6 and $27.8 \mathrm{mmol} / \mathrm{l}$ respectively, by adding phosphated-buffered saline and/or a concentrated glucose solution. After 6 weeks of incubation, somatic point mutations in mDNA were assessed as described earlier.

Mathematical modelling of PCR error. Mathematical modelling of the PCR error [18] was as follows: Let $f$ be the PCR polymerase error rate per base, $L$ the length of the strand to be amplified, $S_{0}$ the initial number of strands and $\eta$ the fraction of molecules replicated in each cycle. The probability of introducing $k$ errors while copying a strand is:

$p(k)=C(L, k) f^{k}(1-f)^{L-k}$.

Let $\mathrm{S}(c, k)$ be the number of strands present after $c$ cycles with $k$ PCR-induced errors. The fraction of strands present after $c$ cycles with $k$ errors is:

$$
\begin{aligned}
F(c, k)= & S(c, k) /\left(S_{0}(1+\eta)^{c}\right) \\
= & {[1 /(1+\eta)][F(c-1, k)} \\
& \left.+\eta \sum_{j \leqslant k} F(c-1, j) p(k-j)\right] .
\end{aligned}
$$

Therefore, the average number of errors per strand is:

$<k>=\sum_{k} F(c, k) k=c f L \eta /(1+\eta)$.

The overall PCR error per base is:

$<k>/ L=c f \eta /(1+\eta)$.
Data analysis. The mutational burden for a given sample was calculated as the number of mutations found divided by the total number of bases examined. The data were reported as the mean \pm SEM. The correlation between variables was calculated by the linear regression analysis of untransformed values. A $p$ value lower than 0.05 was regarded as representing a statistically significant difference. The Mann-Whitney U-test was used to compare quantitive data from two segments of mDNA and two groups. Fisher's exact test was used to compare the ratios of the different kinds of somatic transition mutations. All analyses were done using Statview 5.0J (Abacus Concepts, Berkeley, Calif., USA).

\section{Results}

The PCR error per base calculated during 12 PCR cycles was $\sim 6.00 \times 10^{-4} / \mathrm{bp}$, with an error rate of $\sim 10^{-4}$ per base. To test the overall PCR error per base, we experimentally measured PCR errors by using a single bacterial colony as a template for PCR. Sequencing of 25 recombinant plasmids for segment $\mathrm{A}$ and 32 for segment $\mathrm{B}$ revealed no point mutations, indicating that the overall PCR error per base in the 12 PCR cycles was less than $5.49 \times 10^{-5} / \mathrm{bp}$. When all the molecules had been replicated during each cycle, the PCR error rate was less than $9.15 \times 10^{-6} / \mathrm{bp}$.

The frequency of germ-line mutations (polymorphisms) was significantly higher in segment $\mathrm{A}$ than in segment B $\left(49.51 \pm 5.90 \times 10^{-5}\right.$ mutations per bp for A, $1.79 \pm 1.79 \times 10^{-5}$ mutations per bp for $\mathrm{B}$; $p<0.0001$, according to Mann-Whitney U-test). However, no differences were found between segments $\mathrm{A}$ and $\mathrm{B}$ in the frequency of (i) total somatic mutations $\left(44.35 \pm 9.57 \times 10^{-5}\right.$ mutations per bp and 59.06 \pm $10.94 \times 10^{-5}$ mutations per bp; Table 2), (ii) transversion mutations $\left(6.19 \pm 3.23 \times 10^{-5}\right.$ and $\left.10.74 \pm 5.55 \times 10^{-5}\right)$, (iii) transition mutations $\left(37.13 \pm 10.22 \times 10^{-5}\right.$ and $44.74 \pm 9.23 \times 10^{-5}$ ), and (iv) insertions and deletions $\left(1.03 \pm 1.03 \times 10^{-5}\right.$ and $\left.3.58 \pm 2.40 \times 10^{-5}\right)$.

Since there were no differences in the mutational burden between the two segments, we assessed the aggregate somatic mutational burden by combining segments A and B. None of the somatic mutations detected in the twenty clones were the same, suggesting that the degree of heteroplasmy was less than $5 \%$. There were no significant differences in the total somatic point mutational burden between the diabetic and control group $\left(49.39 \pm 8.50 \times 10^{-5}\right.$ mutations per bp in patients and $51.93 \pm 12.00 \times 10^{-5}$ mutations per bp in healthy control subjects; $p=0.58$ ).

However, the aggregate somatic transversion mutational burden in diabetic patients was significantly higher than in the control subjects $\left(13.93 \pm 4.57 \times 10^{-5}\right.$ mutations per bp vs $1.27 \pm 1.27 \times 10^{-5}$ mutations per bp; $p=0.031$; Fig. 1a), while no significant differences were found when two segments were analysed separately ( $p=0.30$ and 0.068 , in segments $\mathrm{A}$ and $\mathrm{B}$ respectively). The frequency of somatic transition point mutations was not different between the two groups 


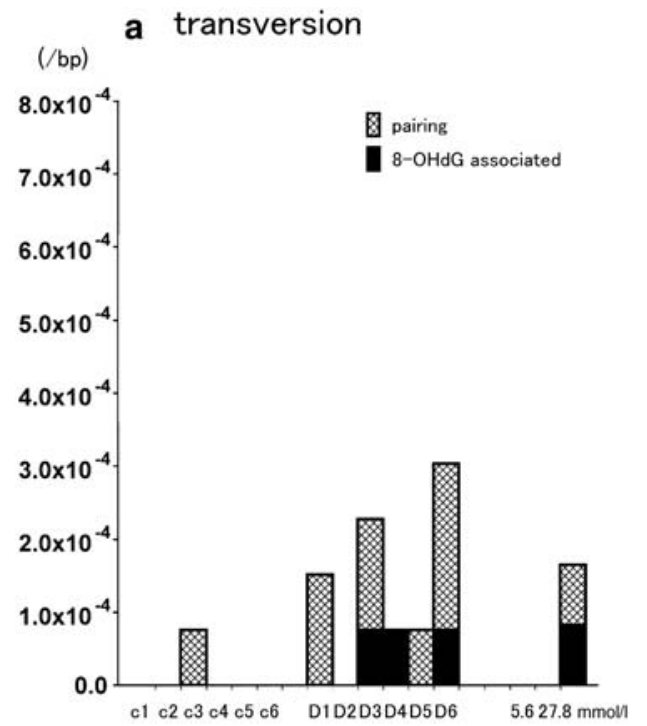

Fig. 1a, b. Aggregate incidence of somatic mutations in leucocyte mDNA from control subjects (c1-c6), diabetic patients (D1-D6) and HL-60 grown for 3 weeks at glucose concentrations of 5.6 and $27.8 \mathrm{mmol} / \mathrm{l}$. The aggregate transversion mutational burden (number of transversion mutations found in multiple clones, divided by the total number of bps sequenced per subject) is shown (a) for each of six samples from control subjects and from patients with diabetes, and for one sample of

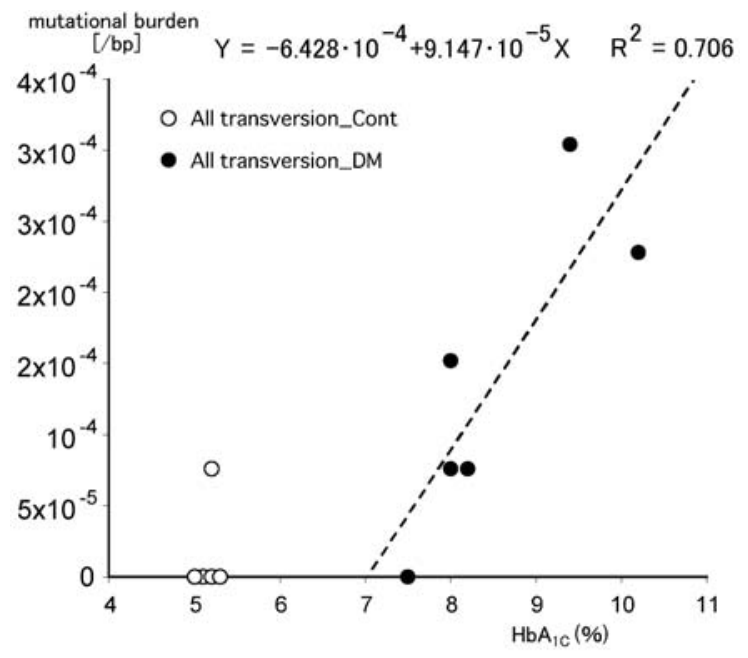

Fig. 2. $\mathrm{HbA}_{1} \mathrm{c}$ values and somatic transversion mutational burden of mDNA in peripheral blood cells from control subjects and diabetic patients. The white circles represent total transversion in control subjects. The black circles represent total transversion in diabetic subjects. Among diabetic patients there is a positive correlation between the incidence of somatic transversion mutations and $\mathrm{HbA}_{1} \mathrm{c}$ values $\left(r=0.840, r^{2}=0.706\right.$, $p=0.036 ; Y=-6.428 * 10^{-4}+9.147 * 10^{-5} \mathrm{X}$, according to linear regression analysis)

$\left(31.66 \pm 6.63 \times 10^{-5} \quad\right.$ vs $50.65 \pm 12.35 \times 10^{-5} ; \quad p=0.17$; Fig. 1b). Interestingly, insertions (1) and deletions (2) were detected in only three diabetic patients. In addition, the linear regression analysis showed a signifi- b transition

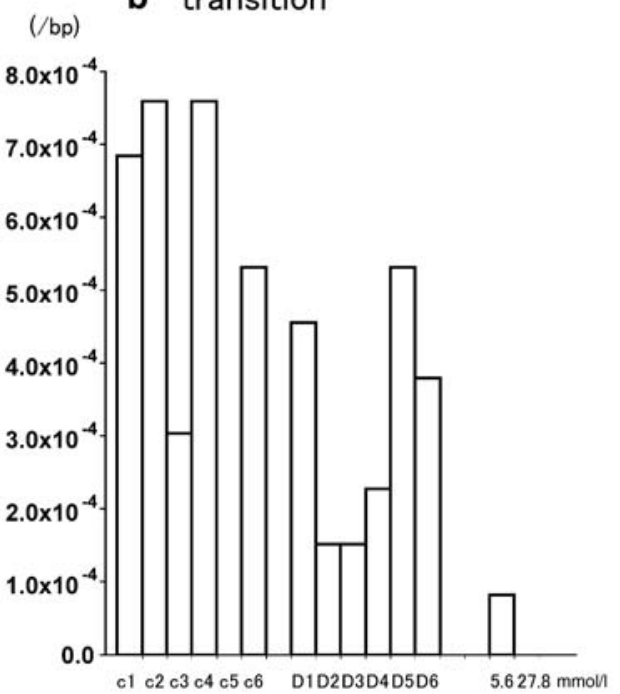

HL-60 per glucose concentration. The black bar represents 8-OHdG-associated transversion mutation. The double-hatched bar represents the other transversion mutations between WatsonCrick base pair; like A:T site to T:A site, or $\mathrm{G}: \mathrm{C}$ site to $\mathrm{C}: \mathrm{G}$ site, or vice-versa. The aggregate transition mutational burden (number of transition mutations found in multiple clones, divided by the total number of bps sequenced per subject) is shown in a similar way (b)

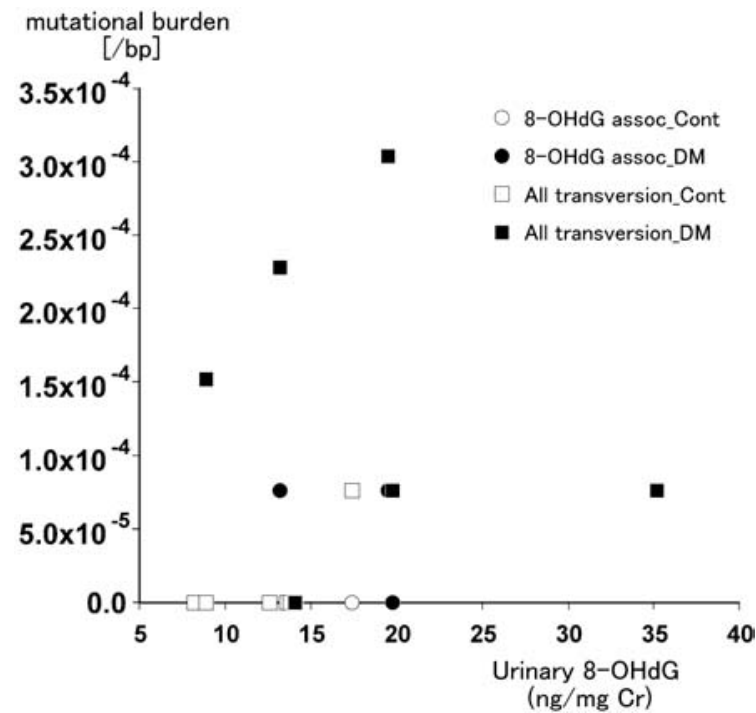

Fig. 3. Urinary $8-\mathrm{OHdG}$ and somatic transversion mutational burden in leucocyte mDNA from control subjects and diabetic patients. Including all samples from all subjects, there is a negative correlation between the total number of transversion mutations, 8-OHdG-associated transversion mutations and urinary $8-\mathrm{OHdG}$. The white square represents total transversion in control subjects. The black square represents total transversion in diabetic subjects. 8-OHdG-associated transversion mutations in control subjects are depicted by white circles. In diabetic patients they are depicted by black circles

cant correlation between aggregate somatic transversion mutational burden and $\mathrm{HbA}_{1} \mathrm{c}$ values in diabetic patients $\left(r=0.840, r^{2}=0.706, p=0.036\right.$; Fig. 2$)$. The $\mathrm{HbA}_{1} \mathrm{c}$ values were $8.55 \pm 1.03 \%$ in patients with dia- 


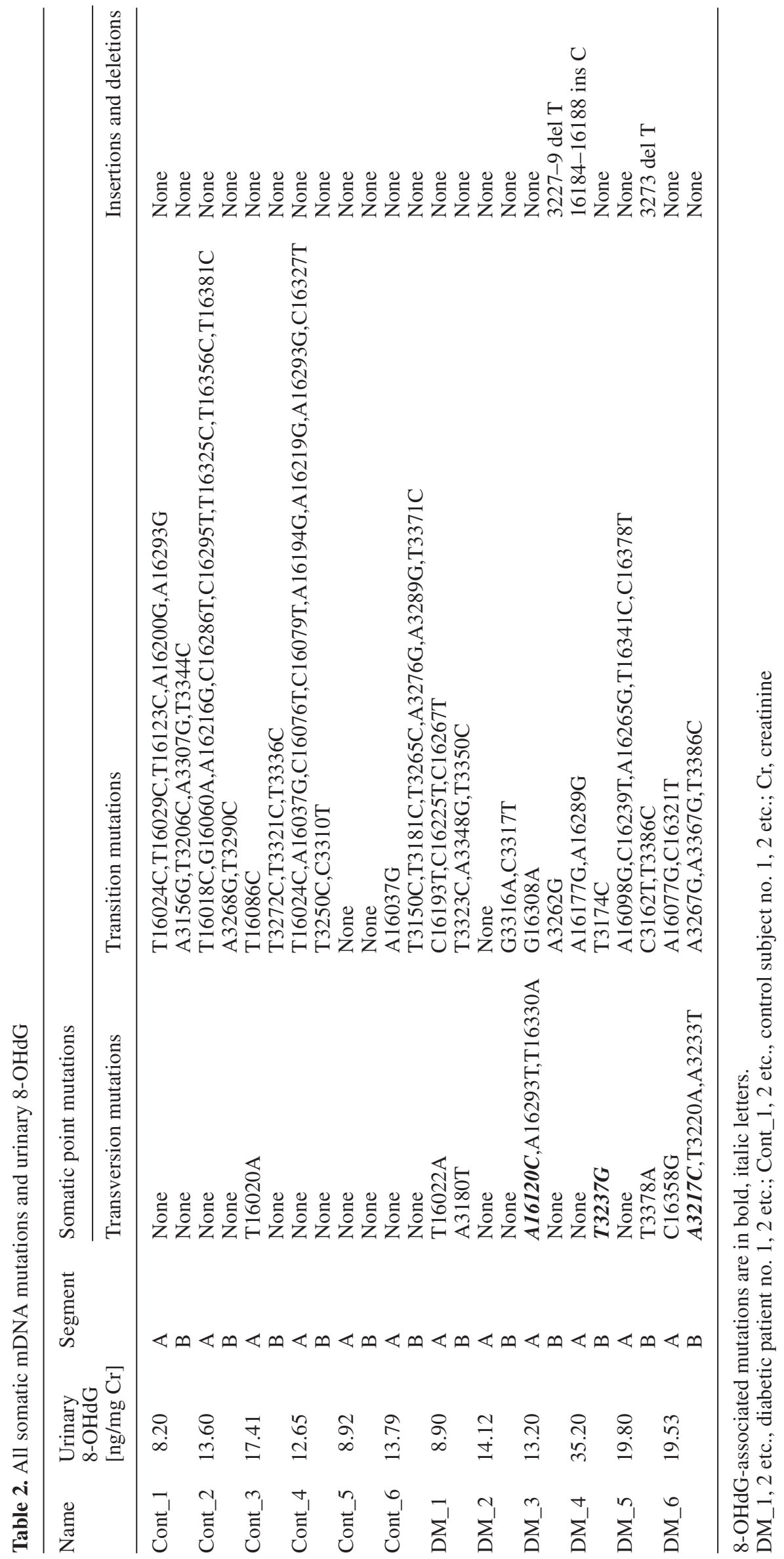


betes mellitus and $5.13 \pm 0.12 \%$ in the control subjects $(p<0.005)$. Moreover, two transversion mutations including one "8-OHdG-associated mutation" were detected from 30 clones of mDNA from HL60 cells cultured at a glucose concentration of $27.8 \mathrm{mmol} / \mathrm{l}$. At a glucose concentration of $5.6 \mathrm{mmol} / \mathrm{l}$ one transition mutation was found (Fig. 1a, b).

The amount of $8-\mathrm{OHdG}$ in the urine tended to be slightly larger in diabetic patients than in control subjects $(18.46 \pm 3.75 \mathrm{ng} / \mathrm{mg}$ creatinine compared with $12.43 \pm 1.39 \mathrm{ng} / \mathrm{mg}$ creatinine). Urinary $8-\mathrm{OHdG}$ was not correlated with the amount of transversion or transition point mutations of mDNA in any of the subjects (Fig. 3). Also no relation was found between age and $\mathrm{HbA}_{1} \mathrm{c}$ values. We only observed 8-OHdG-associated transversion mutations in three patients with diabetes mellitus, and at $22.64 \pm 6.54 \mathrm{ng} / \mathrm{mg}$ creatinine their average concentration of urinary 8-OHdG was slightly higher than in the other diabetic patients.

\section{Discussion}

By means of a method similar to one already used [18], we directly assessed the aggregate burden of somatic point mutations in two segments of mDNA by using a PCR-cloning-sequencing strategy to detect acquired somatic point mutations. In our study it was necessary to take the PCR error into account. Taq DNA polymerase has an assumed error rate of $\sim 10^{-4}$ per base per doubling, resulting mainly in A:T to G:C transition mutations. Other artefacts such as heat-induced mutagenesis can also be created during PCR [44]. To keep the PCR error per base at a minimum, we used only 12 PCR cycles. According to the mathematical formula [18], the artificial mutational burden during 12 cycles of PCR with an error rate of $\sim 10^{-4}$ per base per doubling was $\sim 6.00 \times 10^{-4} / \mathrm{bp}$. However, the calculated artificial mutational burden was much higher than the $5.49 \times 10^{-5} / \mathrm{bp}$ which we obtained by the experimental assessment of PCR error per base. This indicates that under the conditions of our experiment the true error rate of Taq DNA polymerase was lower than expected. Our method was designed to systematically detect precise somatic point mutations even when the degree of heteroplasmy was low. Therefore we believe that our method was particularly effective for studying somatic mutations.

The control region (D-loop) is known to be the most variable portion of the mDNA genome [17]. Our estimated aggregate somatic point mutational burden was of a similar size to the aggregate mutational burden found in the D-loop of two elderly persons

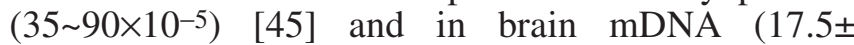
$15.9 \times 10^{-5}$ mutations per bp in all elderly subjects) [18]. As in our study, somatic transition mutations were also shown to be a major part of total somatic mutations $[18,45]$.
With regard to the reported somatic transition mutations caused by oxidation, oxidised $\mathrm{C}$ has been reported to cause $\mathrm{C}$ to $\mathrm{T}$ transition mutations from oxidative stress in E. coli [22]. These $\mathrm{C}$ to $\mathrm{T}$ or $\mathrm{G}$ to $\mathrm{A}$ transition mutations accounted for only a small percent of the somatic transition mutations detected in our study (10/25 in diabetic patients and $7 / 40$ in control subjects, $p=0.17$ according to Fisher's exact test). There were also no mutual relations between these transition mutations, $\mathrm{HbA}_{1} \mathrm{c}$ values and urinary 8-OHdG. Other studies have also used peripheral blood cells to examine the accumulation of A3243G mutations in mDNA of diabetic patients, quantifying its mutational burden as $5.2 \pm 0.3 \times 10^{-5}$ mutations per bp [16]. Even allowing for the PCR error $(\sim 5.49 \times$ $10^{-5} / \mathrm{bp}$ ), this value is much lower than ours $\left(31.66 \pm 6.63 \times 10^{-5} / \mathrm{bp}\right)$. Hence, it is possible that $\mathrm{nt}$ 3,243 is not a hot point for mutation as stated in that report.

Concerning the correlation we found between the incidence of somatic transversion mutations in mDNA and $\mathrm{HbA}_{1} \mathrm{c}$ values, many reports have dealt with somatic mutations in mDNA. Most of them, however, have been on somatic transition mutations, deletions and insertions, whereas somatic transversion mutations have never been reported. In addition, only few documents exist on somatic point mutations associated with hyperglycaemia or $\mathrm{HbA}_{1} \mathrm{c}$ values. Our in vitro experiment using HL60 cells supported our findings on somatic transversion mutations in vivo.

In our study 8-OHdG in the urine of the diabetic patients was only a little higher than that in control subjects, although previous papers $[7,9,13]$ showed considerably higher concentrations of urinary $8-\mathrm{OHdG}$ in patients with diabetes mellitus. In addition, no correlation was found between urinary $8-\mathrm{OHdG}$ and the transversion mutational burden. However, oxidative stress is reported to be increased in people with diabetes mellitus or hyperglycaemia $[3,4,5,6,7,8,9,10,11$, $12,13,14,15]$, suggesting that the somatic transversion mutational burden of mDNA is associated with oxidative stress derived from hyperglycaemia, which is not reflected by urinary $8-\mathrm{OHdG}$.

Concentrations of urinary $8-\mathrm{OHdG}$ in three diabetic patients who had microangiopathy or macroangiopathy or both, and also had 8-OHdG-associated mutations, were much higher than in the other subjects. These findings confirm the conventional idea $[5,9$, $13,15]$ that $8-\mathrm{OHdG}$ is connected with diabetic complications. Mutations associated with $8-\mathrm{OHdG}$ have not previously been shown in patients with diabetic complications. However, our study only detected three 8-OHdG-associated mutations, which did not correlate with $\mathrm{HbA}_{1} \mathrm{c}$ values.

It is possible that somatic mutations associated with hyperglycaemia occur not only in mDNA, but also in nDNA in very small amounts. In the light of many reports on diabetic complications in association 
with hyperglycaemia or $\mathrm{HbA}_{1} \mathrm{c}$ values [46, 47, 48], it is possible that such somatic transversion mutations also partly contribute to diabetic complications. Alternatively, common mechanisms could result in the complications and the somatic transversion mutations associated with hyperglycaemia. In conclusion, the increase detected by us in somatic transversion point mutations in mDNA from diabetic patients could be used as a novel biomarker.

Acknowledgements. We extend special thanks to: Dr S. Ohta (Department of Preventive Medicine, Shinshu University School of Medicine, Matsumoto, Japan) for her useful advice about statistics; Dr D.P. Cioca (2nd Department of Internal Medicine, Shinshu University School of Medicine) for a generous gift of HL-60 cells; Mr. and Mrs. Junker for language assistance; Professor K. Kiyosawa (2nd Department of Internal Medicine, Shinshu University School of Medicine) for his helpful suggestions.

\section{References}

1. Li M, Absher PM, Liang P, Russell JC, Sobel BE, Fukagawa NK (2001) High glucose concentrations induce oxidative damage to mitochondrial DNA in explanted vascular smooth muscle cells. Exp Biol Med (Maywood) 226:450-457

2. Ahrendt SA, Decker PA, Alawi EA et al. (2001) Cigarette smoking is strongly associated with mutation of the K-ras gene in patients with primary adenocarcinoma of the lung. Cancer 92:1525-1530

3. Baynes JW (1991) Role of oxidative stress in development of complications in diabetes. Diabetes 40:405-412

4. Aoki Y, Yazaki K, Shirotori K et al. (1993) Stiffening of connective tissue in elderly diabetic patients: relevance to diabetic nephropathy and oxidative stress. Diabetologia 36:79-83

5. Dandona P, Thusu K, Cook S et al. (1996) Oxidative damage to DNA in diabetes mellitus. Lancet 347:444-445

6. Ceriello A, Dello Russo P, Amstad P, Cerutti P (1996) High glucose induces antioxidant enzymes in human endothelial cells in culture. Evidence linking hyperglycemia and oxidative stress. Diabetes 45:471-477

7. Leinonen J, Lehtimaki T, Toyokuni S et al. (1997) New biomarker evidence of oxidative DNA damage in patients with non-insulin-dependent diabetes mellitus. FEBS Lett 417:150-152

8. Ceriello A, Falleti E, Motz E et al. (1998) Hyperglycemiainduced circulating ICAM-1 increase in diabetes mellitus: the possible role of oxidative stress. Horm Metab Res 30:146-149

9. Hinokio Y, Suzuki S, Hirai M, Chiba M, Hirai A, Toyota T (1999) Oxidative DNA damage in diabetes mellitus: its association with diabetic complications. Diabetologia 42:995-998

10. Ihara Y, Toyokuni S, Uchida K et al. (1999) Hyperglycemia causes oxidative stress in pancreatic beta-cells of GK rats, a model of type 2 diabetes. Diabetes 48:927-932

11. Du XL, Edelstein D, Rossetti L et al. (2000) Hyperglycemia-induced mitochondrial superoxide overproduction activates the hexosamine pathway and induces plasminogen activator inhibitor-1 expression by increasing Sp1 glycosylation. Proc Natl Acad Sci USA 97:12222-12226
12. VanderJagt DJ, Harrison JM, Ratliff DM, Hunsaker LA, Vander Jagt DL (2001) Oxidative stress indices in IDDM subjects with and without long-term diabetic complications. Clin Biochem 34:265-270

13. Kakimoto M, Inoguchi T, Sonta T et al. (2002) Accumulation of 8-hydroxy-2'-deoxyguanosine and mitochondrial DNA deletion in kidney of diabetic rats. Diabetes 51:15881595

14. Seghrouchni I, Drai J, Bannier E et al. (2002) Oxidative stress parameters in type I, type II and insulin-treated type 2 diabetes mellitus; insulin treatment efficiency. Clin Chim Acta 321:89-96

15. Suzuki S, Hinokio Y, Komatu K et al. (1999) Oxidative damage to mitochondrial DNA and its relationship to diabetic complications. Diabetes Res Clin Pract 45:161168

16. Nomiyama T, Tanaka Y, Hattori N et al. (2002) Accumulation of somatic mutation in mitochondrial DNA extracted from peripheral blood cells in diabetic patients. Diabetologia 45:1577-1583

17. Michikawa Y, Mazzucchelli F, Bresolin N, Scarlato G, Attardi G (1999) Aging-dependent large accumulation of point mutations in the human mtDNA control region for replication. Science 286:774-779

18. Lin MT, Simon DK, Ahn CH, Kim LM, Beal MF (2002) High aggregate burden of somatic mtDNA point mutations in aging and Alzheimer's disease brain. Hum Mol Genet 11:133-145

19. Nishikawa M, Nishiguchi S, Shiomi S et al. (2001) Somatic mutation of mitochondrial DNA in cancerous and noncancerous liver tissue in individuals with hepatocellular carcinoma. Cancer Res 61:1843-1845

20. Nekhaeva E, Bodyak ND, Kraytsberg Y et al. (2002) Clonally expanded mtDNA point mutations are abundant in individual cells of human tissues. Proc Natl Acad Sci USA 99:5521-5526

21. Duncan BK, Miller JH (1980) Mutagenic deamination of cytosine residues in DNA. Nature 287:560-561

22. Kreutzer DA, Essigmann JM (1998) Oxidized, deaminated cytosines are a source of $\mathrm{C} \rightarrow \mathrm{T}$ transitions in vivo. Proc Natl Acad Sci USA 95:3578-3582

23. Zardo G, Marenzi S, Caiafa P (1998) H1 histone as a transacting factor involved in protecting genomic DNA from full methylation. Biol Chem 379:647-654

24. Lindahl $\mathrm{T}$ (1993) Instability and decay of the primary structure of DNA. Nature 362:709-715

25. Cheng KC, Cahill DS, Kasai H, Nishimura S, Loeb LA (1992) 8-Hydroxyguanine, an abundant form of oxidative DNA damage, causes G-T and A-C substitutions. J Biol Chem 267:166-172

26. Nakabeppu Y (2001) Regulation of intracellular localization of human MTH1, OGG1, and MYH proteins for repair of oxidative DNA damage. Prog Nucleic Acid Res Mol Biol 68:75-94

27. Kino K, Sugiyama H (2001) Possible cause of G-C $\rightarrow$ C-G transversion mutation by guanine oxidation product, imidazolone. Chem Biol 8:369-378

28. Tsuzuki T, Egashira A, Igarashi H et al. (2001) Spontaneous tumorigenesis in mice defective in the MTH1 gene encoding 8-oxo-dGTPase. Proc Natl Acad Sci USA 98:11456-11461

29. Lutsenko EA, Carcamo JM, Golde DW (2002) Vitamin C prevents DNA mutation induced by oxidative stress. J Biol Chem 277:16895-16899

30. Sugden KD, Martin BD (2002) Guanine and 7,8-dihydro8-oxo-guanine-specific oxidation in DNA by chromium(V). Environ Health Perspect 110 (Suppl 5):725-728 
31. Karahalil B, Hogue BA, De Souza-Pinto NC, Bohr VA (2002) Base excision repair capacity in mitochondria and nuclei: tissue-specific variations. FASEB J 16:18951902

32. Bohr VA, Stevnsner T, De Souza-Pinto NC (2002) Mitochondrial DNA repair of oxidative damage in mammalian cells. Gene 286:127-134

33. Richter C, Park JW, Ames BN (1988) Normal oxidative damage to mitochondrial and nuclear DNA is extensive. Proc Natl Acad Sci USA 85:6465-6467

34. Richter C (1988) Do mitochondrial DNA fragments promote cancer and aging? FEBS Lett 241:1-5

35. Yakes FM, Houten B van (1997) Mitochondrial DNA damage is more extensive and persists longer than nuclear DNA damage in human cells following oxidative stress. Proc Natl Acad Sci USA 94:514-519

36. Shibutani S, Takeshita M, Grollman AP (1991) Insertion of specific bases during DNA synthesis past the oxidationdamaged base 8-oxodG. Nature 349:431-434

37. Kuchino Y, Mori F, Kasai H et al. (1987) Misreading of DNA templates containing 8-hydroxydeoxyguanosine at the modified base and at adjacent residues. Nature 327:77-79

38. Bridges BA (1997) MutT prevents leakiness. Science 278:78-79

39. Cooke MS, Evans MD, Herbert KE, Lunec J (2000) Urinary 8-oxo-2'-deoxyguanosine-source, significance and supplements. Free Radic Res 32: 381-397

40. Cooke MS, Evans MD, Lunec J (2002) DNA repair: insights from urinary lesion analysis. Free Radic Res 36:929-932
41. Alberti KG, Zimmet PZ (1998) Definition, diagnosis and classification of diabetes mellitus and its complications. Part 1: diagnosis and classification of diabetes mellitus provisional report of a WHO consultation. Diabet Med 15:539-553

42. Andrews RM, Kubacka I, Chinnery PF, Lightowlers RN, Turnbull DM, Howell N (1999) Reanalysis and revision of the Cambridge reference sequence for human mitochondrial DNA. Nat Genet 23:147

43. Saito S, Yamauchi H, Hasui Y, Kurashige J, Ochi H, Yoshida K (2000) Quantitative determination of urinary 8-hydroxydeoxyguanosine (8-OH-dg) by using ELISA. Res Commun Mol Pathol Pharmacol 107:39-44

44. Andre P, Kim A, Khrapko K, Thilly WG (1997) Fidelity and mutational spectrum of Pfu DNA polymerase on a human mitochondrial DNA sequence. Genome Res 7:843-852

45. Jazin EE, Cavelier L, Eriksson I, Oreland L, Gyllensten U (1996) Human brain contains high levels of heteroplasmy in the noncoding regions of mitochondrial DNA. Proc Natl Acad Sci USA 93:12382-12387

46. Anonymous (1995) The relationship of glycemic exposure (HbA1c) to the risk of development and progression of retinopathy in the Diabetes Control and Complications Trial. Diabetes 44:968-983

47. Anonymous (1996) The absence of a glycemic threshold for the development of long-term complications: the perspective of the Diabetes Control and Complications Trial. Diabetes 45:1289-1298

48. Menzin J, Langley-Hawthorne C, Friedman M, Boulanger L, Cavanaugh R (2001) Potential short-term economic benefits of improved glycemic control: a managed care perspective. Diabetes Care 24:51-55 